\title{
AGRICULTURAL ENTREPRENEURIAL STRATEGY DURING THE COVID-19 PANDEMIC: CASE STUDY OF GARUT, INDONESIA
}

\author{
Eddy Soeryanto Soegoto \\ Department of Management, Universitas Komputer Indonesia, Bandung, Indonesia \\ Senny Luckyardi \\ Department of Management, Universitas Komputer Indonesia, Bandung, Indonesia
}

\begin{abstract}
Lia Warlina
Department of Urban and Regional Planning, Universitas Komputer Indonesia, Bandung, Indonesia
\end{abstract}

Sri Supatmi

Department of Electrical Engineering, Universitas Komputer Indonesia, Bandung, Indonesia

\begin{abstract}
This study aims at proposing a business strategy to maintain the agricultural sector in Garut Regency during the Covid-19 Pandemic. Regardless of the fact that all sectors need special strategies to survive during the COVID-19 pandemic, there are still limited studies focusing on entrepreneurship strategies in the agriculture sector. The method used in this research was descriptive-qualitative with Garut Regency, Indonesia as the case study. Observations were made for a period of one year from October 2019 to October 2020 to observe the resilience of the agricultural sector in Garut district, Indonesia, as primary data and literature review was also used to support this analysis. The data collection results show a reduction in sales and production during the Covid-19 Pandemic due to physical distancing and other social restrictions policies that hinder activities, including the process of purchasing and distributing goods. During the COVID-19 pandemic, the agricultural sector of Garut Regency used a closed-loop strategy, namely by establishing cooperation between farmers and the industrial as well as retail sectors. The success of implementing this strategy is shown from the stable amount of chili agricultural production during the pandemic, as shown in Tables 1 and 2. Therefore, to support this strategy, a supporting strategy that considers internal and external factors in the agricultural sector is needed. This study uses SWOT analysis to determine important aspects in formulating solutions to agricultural problems during the pandemic. Based on the identified factors, various strategies were obtained to strengthen the economic structure of farmers from the short to the long term. As a result, farmers are expected to increase production and welfare as well as can become a momentum for strengthening national food independence. It is hoped that this research can be used as a reference for other researchers in their research and add insight.
\end{abstract}

Keywords: Agriculture, Entrepreneurship, Farmer, Economic, Covid-19, SWOT

DOI: http://dx.doi.org/10.15549/jeecar.v9i1.872

www.ieeca.org/journal 


\section{INTRODUCTION}

Agriculture utilizes biological and natural resources by humans to produce foods, industrial raw materials, or energy sources. It also helps humans to manage their environment (Purba et al., 2020). Farming is a part of agriculture with different fields. Agriculture covers a wide production area, including development, research, and implementation of agricultural activities (Saiz-Rubio and Rovira-Más, 2020). Currently, entrepreneurship in the field of agriculture has become a trend. Agricultural entrepreneurship is a tool to empower rural communities engaged in agriculture to start businesses in improving the welfare of farmers (Dias et al, 2019). Agricultural entrepreneurs are farmers under 45 years old and have managed agricultural land directly. Entrepreneurs in agriculture must have awareness and motivation for entrepreneurship, participating in increasing village growth through sustainable agricultural development programs using technology and broad connectivity to develop agricultural potential (Choudhury and Easwaran, 2019).

Currently, agriculture is one determining factor in achieving sustainable development goals (zero hunger). Therefore, the agricultural sector is currently concerned about its sustainability. Indonesia is one of the agrarian countries with geographical conditions that have the potential for the agricultural sector, contributing to achieving sustainable development goals. It is shown by Indonesia's contribution in making agriculture the primary source of livelihood. Based on Statistics Indonesia (BPS) data, the most significant number of workers in the agricultural sector as of August 2020 was 38.23 million workers, or $29.76 \%$ of the total of 128.45 million Indonesian workforces (Mukti et al, 2020). The trend of agricultural development in Indonesia currently leads to agricultural entrepreneurship in the form of agricultural business, livestock business, fishery business, manufacturing business, tourism service business, and others (Perwita, 2020). The agricultural sub-sector that is widely developed and cultivated in Indonesia is horticulture. Horticultural products have the second-highest export value of agricultural products compared to other plantation subsectors. Red chili pepper (Capsicum annum L.) is one of the leading horticultural commodities in Indonesia. One of the largest chili-producing provinces in Indonesia is West Java Province, with a total production of $\pm 22.9 \%$ (Hayuningtyas \& Yuliasih, 2020).

Chili is one of the commodities that affect inflation experienced by Indonesia in 2010; chili contributed 0.32 to the total inflation of $6.96 \%$. However, from 2017 to 2019, chili production increased by 6.47 to $25.53 \%$ (Mariyono and Sumarno, 2015). Therefore, development in the agricultural sector is needed to increase the quantity and quality of Indonesian chili. The support was done by several programs such as Food Security Improvement Programs, Agribusiness Development, Farmers' Welfare Improvement, and Rural Agribusiness Development (PUAP) (Alamsyah et al., 2015).

Therefore, this study proposes a business strategy through SWOT analysis to maintain the chili agricultural sector during the Covid-19 Pandemic in Garut Regency. This research used descriptive-qualitative observation and interviews as primary data collection techniques and Literature Review as secondary data collection techniques.

\section{LITERATURE REVIEW}

\section{Agriculture sector before and during the pandemic}

The development of the global agricultural sector is facing the Covid-19 Pandemic in 2021. It will experience many changes, including consumer behavior, technological disruption, international trade policies, fiscal and monetary stimulus measures, as well as the transformation of the food system (Outlook Ekonomi Pertanian, 2021). The same thing also happened in Indonesia. The agricultural sector in Indonesia can supply important commodities such as natural rubber, coffee, cocoa, palm oil, rice, and spices worldwide. Therefore, the role of the agricultural sector in 2020 needs to be maintained and improved to encourage economic growth in 2021. However, the production of food and horticulture crops in Indonesia is relatively low, which results in a high import of horticultural products. Garut regency became one of the agriculture centers in Indonesia. Garut Regency has potential in agriculture with a variety of commodities. Agriculture in Garut Regency is the main livelihood of the local people because the area is located at an altitude of 1300 masl. This altitude is suitable for the development of the agricultural sector. 
Agricultural commodities cultivated in Garut Regency, including chili, corn, mustard greens, cabbage, tomatoes, shallots, citrus, and others. Therefore, with high yields from the agricultural sector, Garut Regency is an area that supplies the food needs of people in its surrounding area, such as Bandung, Jakarta, and others. Garut Regency's contribution to the economy in the agricultural sector in the surrounding area is 40\% (RPIJM Garut Regency, 2015-2019). The high role of this sector is due to agricultural management, which tends to be traditional and does not depend on imported materials. Therefore, it is based on simple technology. However, it has resulted in slower economic growth in Garut Regency than other regencies in West Java Province (Zuraida, 2011).

Therefore, to increase the growth rate in Garut Regency and improve its quality, it is necessary to implement agricultural entrepreneurship (Putra, 2020; Poapongsakorn, 2017). Agricultural entrepreneurship can be applied with entrepreneurship public awareness and good business management skills. Moreover, they can have competitiveness to face changes in the agricultural business.

\section{The Agricultural Sector Role in a Country's Economy}

Asia is the most productive region in producing products in this sector compared to other continents. It is supported by climatic conditions that are suitable for agricultural activities. The production value of the Asian agricultural sector from 2007 to 2016 was the highest compared to other continents, with an average total production of $\$ 1.22$ trillion and a growth of $2.5 \%$ per year. One of the centers of agriculture in Southeast Asia is Thailand. Agriculture in Thailand is one of the most important economic sectors, as shown from the number of workers that reach $30 \%$ of the total workforce. It is also experienced by Assam, Northeast India, where entrepreneurship in the agricultural and agribusiness sectors improves village development, especially villages with the geographical potential for various crops and horticultural productivity (Moromi, \& Debayit, 2016). Another country in Central Asia also utilizes the agricultural sector in its economic development in Kazakhstan.

According to 2019 OECD data, Kazakhstan's agricultural sector, grain export, makes up about
$4.5 \%$ of the country's economic production (Choudhury \& Easwaran, 2019; Kazakhstan, 2019).

The data from several countries above shows that the agricultural sector is one of the leading sectors as the economic support for the various Asian countries economies. The agricultural sector is supported by climate and geographical conditions suitable of farming activities.

\section{METHOD}

The method used in this study was the descriptive-qualitative method using a case study. The primary data collection technique is observation to Garut Regency, specifically in Cigedug subdistrict as the chili center. It is chosen because the subdistrict can support chili commodity needs in the agricultural sector in West Java province by $38 \%$. It is also nationally contributed by $10-12 \%$ to the national chili demand. The primary data collection was carried out by interviewing farmer groups to determine the reach of agricultural areas. It is also done to determine which plant types will be produced and planting period or information regarding the distribution of products to the market, supported by field observations. Meanwhile, the secondary data collection techniques used the Literature Review on agriculture entrepreneurship and statistical reviews of data from the Central Statistics Agency and Garut Regency agriculture office.

SWOT is a strategic analysis technique that aims at identifying the strengths and weaknesses of the object under study to achieve the desired target. SWOT is an acronym for Strength, Weakness, Opportunity, and Threat. It is applied by analyzing and sorting out various factors that affect the four factors and mapped in a SWOT matrix (Table 1).

As shown in Table 1, Strength is an internal factor that can take advantage of Opportunity and avoid Threats, while weakness is an internal factor that can manifest Threat and prevent Opportunity. In addition, Opportunity is an external factor that can be used by a business to overcome weaknesses, and Threat is an external factor that can prevent business goals achievement. 
Table 1: SWOT Analysis Matrix

\begin{tabular}{|l|l|l|}
\hline & Strengths & Weakness \\
& 1. & 1. \\
& 2. & 2. \\
& 3. & 3. \\
& 4. & 4. \\
\hline Opportunities & Opportunities-Strength strategies: & Opportunities-Weakness strategies: \\
1. & Use strengths to take advantage of & Overcome weakness by taking \\
2. & opportunities & advantage of opportunities \\
3. & 1. & \\
4. & 2. & Threats-Weakness strategies: \\
Threats & Threats-Strength strategies: Use & Minimize weakness and avoid threats \\
1. & strength to avoid threats & 1. \\
2. & 1. & 2. \\
3. & 2. & \\
4. & & \\
\hline
\end{tabular}

\section{RESULTS AND DISCUSSION}

\section{Garut Regency Agricultural Sector Production} Data

One of the leading commodities in the agricultural sector in Garut Regency is chili, consisting of chili pepper (Capsicum frutescens) and red chili pepper (Capsicum annuum L.). Based on data from the BPS for Chili Production in Garut Regency in 2017, chili farmers from 42 subdistricts produced a total chili production of $1,731,770$ quintals. The type of red chili pepper with a total production of $1,143,240$ quintals, while chili pepper produces 588,530 quintals. However, with the availability of labor mobilization, farmers have difficulty obtaining fertilizer, feed, and agricultural spare parts due to distribution disruptions. It has a large influence on the production chain of agricultural commodities.

Table 2: Chili Production Data in Garut Regency on 2019

\begin{tabular}{|c|c|c|c|c|c|c|}
\hline \multirow[b]{2}{*}{ No } & \multirow[b]{2}{*}{ Subdistrict } & \multirow[b]{2}{*}{$\begin{array}{l}\text { Red Chili Pepper } \\
\text { Harvest Area (Ha) }\end{array}$} & \multirow[b]{2}{*}{$\begin{array}{l}\text { Chili harvest } \\
\text { area (Ha) }\end{array}$} & \multicolumn{3}{|c|}{ Productions (quintal) } \\
\hline & & & & $\begin{array}{l}\text { Red Chili } \\
\text { Pepper }\end{array}$ & $\begin{array}{c}\text { Chili } \\
\text { pepper }\end{array}$ & Total \\
\hline 1 & Cisewu & 118 & 96 & 16420 & 29440 & 32982 \\
\hline 2 & Caringin & 649 & 244 & 79825 & 145723 & 103241 \\
\hline 3 & Talegong & 84 & 36 & 18799 & 27280 & 17729 \\
\hline 4 & Bungbulang & 0 & 70 & 0 & 19799 & 11386 \\
\hline 5 & Mekarmukti & 0 & 38 & 0 & 16975 & 5264 \\
\hline 6 & Pamulihan & 125 & 100 & 16060 & 27648 & 31922 \\
\hline 7 & Pakenjeng & 138 & 64 & 21514 & 28762 & 25251 \\
\hline 8 & Cikelet & 20 & 16 & 1770 & 2920 & 3431 \\
\hline 9 & Pameungpeuk & 2 & 1 & 268 & 521 & 138 \\
\hline 10 & Cibalong & 0 & 21 & 0 & 1017 & 3371 \\
\hline 11 & Cisompet & 0 & 5 & 0 & 4305 & 720 \\
\hline 12 & Peundeuy & 61 & 42 & 8985 & 14431 & 20264 \\
\hline 13 & Singajaya & 30 & 10 & 4448 & 5610 & 6286 \\
\hline 14 & Cihurip & 4 & 10 & 490 & 756 & 3601 \\
\hline 15 & Cikajang & 527 & 413 & 75781 & 127962 & 128314 \\
\hline 16 & Banjarwangi & 84 & 61 & 12564 & 19778 & 20324 \\
\hline 17 & Cilawu & 506 & 223 & 47907 & 70862 & 126604 \\
\hline 18 & Bayongbong & 192 & 58 & 30035 & 36554 & 49099 \\
\hline 19 & Cigedug & 311 & 238 & 46252 & 74941 & 82500 \\
\hline 20 & Cisurupan & 558 & 332 & 78417 & 112345 & 145749 \\
\hline
\end{tabular}


Table 2: Continued

\begin{tabular}{|l|l|r|r|r|r|r|}
\hline 21 & Sukaresmi & 317 & 207 & 46810 & 74505 & 70870 \\
\hline 22 & Samarang & 197 & 185 & 30073 & 41975 & 80742 \\
\hline 23 & Pasirwangi & 337 & 361 & 46420 & 78267 & 105819 \\
\hline 24 & Tarogong Kidul & 5 & 6 & 553 & 791 & 1798 \\
\hline 25 & Tarogong Kaler & 73 & 6 & 11205 & 14781 & 2916 \\
\hline 26 & Garut Kota & 44 & 9 & 6740 & 11153 & 2971 \\
\hline 27 & Karangpawitan & 137 & 27 & 19691 & 22888 & 24915 \\
\hline 28 & Wanaraja & 248 & 42 & 33146 & 38457 & 44286 \\
\hline 29 & Sucinaraja & 325 & 66 & 48581 & 59078 & 51495 \\
\hline 30 & Pangatikan & 352 & 19 & 48829 & 71424 & 55867 \\
\hline 31 & Sukawening & 58 & 9 & 8548 & 10141 & 8865 \\
\hline 32 & Karangtengah & 15 & 11 & 1943 & 3214 & 4054 \\
\hline 33 & Banyuresmi & 671 & 59 & 98884 & 102999 & 109143 \\
\hline 34 & Leles & 177 & 35 & 26373 & 27830 & 35917 \\
\hline 35 & Leuwigoong & 23 & 23 & 3334 & 5168 & 7841 \\
\hline 36 & Cibatu & 26 & 28 & 3503 & 10188 & 7837 \\
\hline 37 & Kersamanah & 0 & 0 & 0 & 0 & 507 \\
\hline 38 & Cibiuk & 41 & 28 & 5559 & 9374 & 9176 \\
\hline 39 & Kadungora & 64 & 21 & 9571 & 14873 & 8810 \\
\hline 40 & Blubur & 18 & 12 & 2756 & 5693 & 5048 \\
& Limbangan & & & & & 689 \\
\hline 41 & Selaawi & 86 & 4 & 1363 & 13952 & 17502 \\
\hline 42 & Malangbong & 6672 & 3.241 & $\mathbf{9 2 5 6 9 0}$ & $\mathbf{4 5 9 9 0 7}$ & 1385597 \\
\hline Total & & & & & \\
\hline
\end{tabular}

Source: BPS Garut Regency Chili Production in 2019

It is proven by the total chili production in Garut Regency in 2020 (during the pandemic) is $1,475,244$ quintals, with the production of red chili pepper as much as $1,013,184$ quintals (down $\pm 11.38 \%$ ), and 462,060 quintals for chili (down \pm 21 ). ,49\%). From tables 2 and 3, it is shown that the production of chili commodities in Garut district during the covid-19 pandemic can survive and increase.
Table 3 shows the total production of red chili pepper and chili pepper in Garut Regency by subdistricts. The subdistrict with the largest production yield for red chili pepper in 2020 is the Cisurupan subdistrict, which is 101.772 quintals with a harvested area of 657 ha. As for chili, it is produced by the Cikajang subdistrict with a total production of 54,797 quintals in 413 ha.

Table 3: Chili Production Data in Garut Regency on 2020

\begin{tabular}{|l|l|r|r|r|r|r|}
\hline \multirow{2}{*}{ No } & Subdistrict & $\begin{array}{l}\text { Red Chili } \\
\text { Pepper } \\
\text { Harvest Area } \\
\text { (Ha) }\end{array}$ & \multirow{2}{*}{$\begin{array}{l}\text { Chili harvest } \\
\text { area (Ha) }\end{array}$} & $\begin{array}{l}\text { Red Chili } \\
\text { Pepper }\end{array}$ & $\begin{array}{l}\text { Chili } \\
\text { pepper }\end{array}$ & Total \\
\hline 1 & Cisewu & 118 & 96 & 18813 & 14169 & 32982 \\
\hline 2 & Caringin & 459 & 244 & 69229 & 34012 & 103241 \\
\hline 3 & Talegong & 84 & 36 & 12791 & 4938 & 17729 \\
\hline 4 & Bungbulang & 0 & 70 & 0 & 11386 & 11386 \\
\hline 5 & Mekarmukti & 0 & 38 & 0 & 5264 & 5264 \\
\hline 6 & Pamulihan & 116 & 100 & 18204 & 13718 & 31922 \\
\hline 7 & Pakenjeng & 108 & 64 & 16193 & 9058 & 25251 \\
\hline 8 & Cikelet & 8 & 16 & 1477 & 1954 & 3431 \\
\hline 9 & Pameungpeuk & 0 & 1 & 0 & 138 & 138 \\
\hline 10 & Cibalong & 3 & 21 & 487 & 2884 & 3371 \\
\hline 11 & Cisompet & 0 & 5 & 0 & 720 & 720 \\
\hline 12 & Peundeuy & 98 & 42 & 14819 & 5445 & 20264 \\
\hline
\end{tabular}


Table 3: Continued

\begin{tabular}{|c|c|c|c|c|c|c|}
\hline 13 & Singajaya & 24 & 10 & 4367 & 1919 & 6286 \\
\hline 14 & Cihurip & 13 & 10 & 2045 & 1556 & 3601 \\
\hline 15 & Cikajang & 495 & 413 & 73517 & 54797 & 128314 \\
\hline 16 & Banjarwangi & 83 & 61 & 12480 & 7844 & 20324 \\
\hline 17 & Cilawu & 468 & 223 & 76838 & 49766 & 126604 \\
\hline 18 & Bayongbong & 292 & 58 & 41291 & 7808 & 49099 \\
\hline 19 & Cigedug & 367 & 238 & 52165 & 30335 & 82500 \\
\hline 20 & Cisurupan & 657 & 332 & 101772 & 43977 & 145749 \\
\hline 21 & Sukaresmi & 286 & 207 & 43430 & 27440 & 70870 \\
\hline 22 & Samarang & 378 & 185 & 56139 & 24603 & 80742 \\
\hline 23 & Pasirwangi & 386 & 361 & 57506 & 48313 & 105819 \\
\hline 24 & Tarogong Kidul & 6 & 6 & 933 & 865 & 1798 \\
\hline 25 & Tarogong Kaler & 12 & 6 & 2021 & 895 & 2916 \\
\hline 26 & Garut Kota & 11 & 9 & 1711 & 1260 & 2971 \\
\hline 27 & Karangpawitan & 138 & 27 & 21232 & 3683 & 24915 \\
\hline 28 & Wanaraja & 239 & 42 & 37511 & 6775 & 44286 \\
\hline 29 & Sucinaraja & 284 & 66 & 42451 & 9044 & 51495 \\
\hline 30 & Pangatikan & 308 & 19 & 52664 & 3203 & 55867 \\
\hline 31 & Sukawening & 52 & 9 & 7715 & 1150 & 8865 \\
\hline 32 & Karangtengah & 14 & 11 & 2592 & 1462 & 4054 \\
\hline 33 & Banyuresmi & 636 & 59 & 100911 & 8232 & 109143 \\
\hline 34 & Leles & 222 & 35 & 31160 & 4757 & 35917 \\
\hline 35 & Leuwigoong & 29 & 23 & 4467 & 3374 & 7841 \\
\hline 36 & Cibatu & 19 & 28 & 3083 & 4754 & 7837 \\
\hline 37 & Kersamanah & 3 & 0 & 507 & 0 & 507 \\
\hline 38 & Cibiuk & 35 & 28 & 5377 & 3799 & 9176 \\
\hline 39 & Kadungora & 40 & 21 & 5998 & 2812 & 8810 \\
\hline 40 & $\begin{array}{l}\text { Blubur } \\
\text { Limbangan }\end{array}$ & 14 & 12 & 2364 & 2684 & 5048 \\
\hline 41 & Selaawi & 0 & 5 & 0 & 689 & 689 \\
\hline 42 & Malangbong & 99 & 4 & 16924 & 578 & 17502 \\
\hline \multicolumn{2}{|c|}{ Total } & 6604 & 3.241 & 1013184 & 462060 & 1475244 \\
\hline
\end{tabular}

Source: BPS Garut Regency Chili Production in 2020

To clarify the distribution of chili production data, it will be presented on a map to provide a clearer visualization based on its geographical value. Figure 1 illustrates chili production data, which is grouped into 5 groups based on their production, namely < 2,500, 2,500 - 5,000, 5,001 - 7,500, 7,501 10,000 , and >10,000. A different color represents each group.

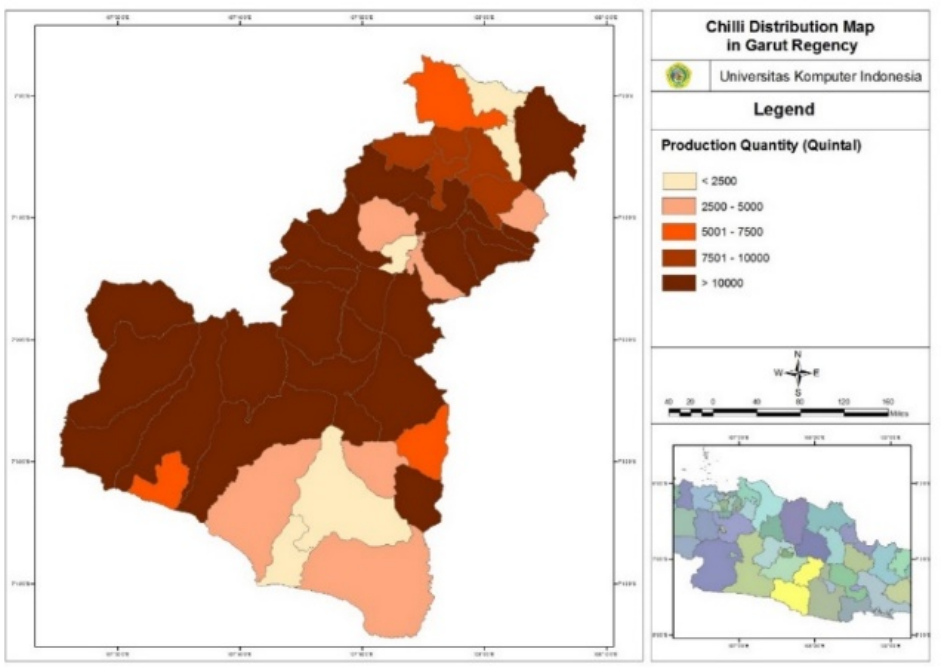

Figure 1: Chili Distribution Map in Garut Regency 
Figure 1 shows that every subdistrict in Garut Regency has many chilies production, which is marked by a densely colored area. The map also shows that Garut Regency is an agricultural center, especially chili, that can support agricultural products in Indonesia.

\section{Closed Loop Strategy in Garut Regency}

During the COVID-19 pandemic in Indonesia, in 2020 Garut Regency used a closed-loop strategy to maintain and improve the welfare of farmers. The closed-loop strategy is applied using the concept of Closed-Loop Marketing, namely by utilizing long-term relationships between consumers, investors, and companies. In agriculture in Garut Regency, the closed-loop strategy synergizes the agricultural value chain, from upstream to downstream, to create competitive and equitable efficiency. The initial implementation of this strategy was carried out in the Eptilu Agrotourism Area of 3 hectares spread across the Cigedug District. The success of this application encourages the implementation of a closed-loop strategy in every agricultural area in Garut Regency. The agricultural scheme of the Closed Loop System in the manufacture of superior chilli seeds in collaboration with PT Ewindo is shown in Figure 2.

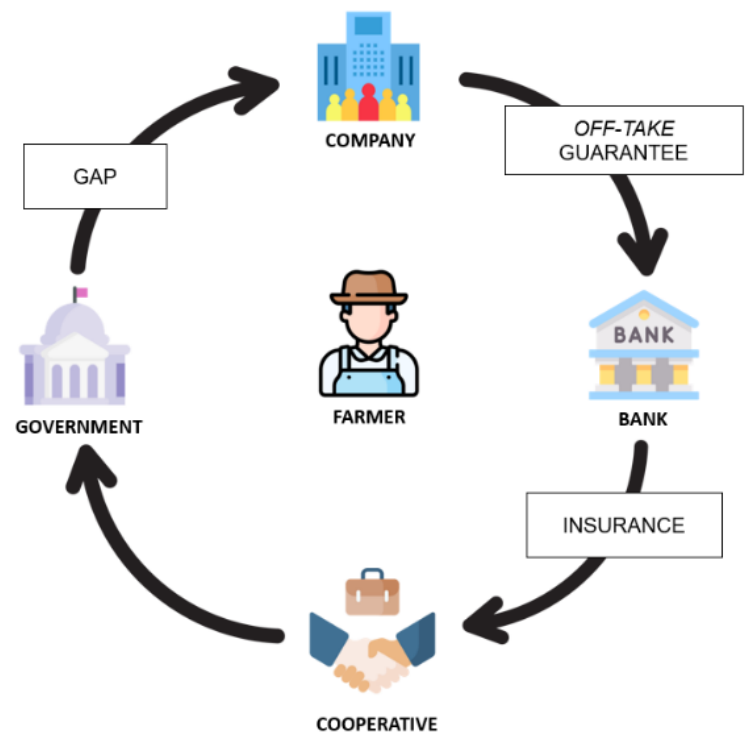

Figure 2: Closed Loop Strategy

The Closed Loop System farming scheme considers 6 crucial aspects, namely:

1. A well-established customer relationship will affect the average income level of Garut Regency farmers. However, several important factors are considered in maintaining customer relationships, customer acquisition, customer base development, and customer behavior.

2. The customer life cycle is a scheme to tie agricultural commodity customers (companies, government, or private) to farmers or suppliers in the long term. Therefore, it is necessary to optimize the values of the customer experience from start to finish when buying products with farmers in Garut Regency.

3. The customer segment is a segment that pays attention to each customer's interests, preferences, and desires from agricultural commodities in Garut Regency. The types of customers can be divided based on segments supporting the buying process, decision making, and increasing the relevance of marketing activities.

4. Multichannel marketing is the interaction of agricultural commodity customers with diverse farmers. Channels relevant to the target group and a multichannel approach can guide communication behavior so that customers can choose their preferred channel for themselves. The integrated approach ensures coherent communication along the customer funnel.

5. The touchpoint consists of digital channels and offline interactions that are part of the customer and farmer touchpoints. The customer's brand experience is shaped by paying attention to brand awareness, upselling and cross-selling, retargeting.

6. The customer journey is a factor in making purchasing decisions. These factors include channels, points of contact, and customer contact.

\section{Internal and External Factors Identification}

Various efforts have been made to find the suitable model to anticipate the ongoing impact of the Covid-19 Pandemic. The Indonesian agricultural sector, especially agriculture with chili commodities in Garut Regency, needs to develop appropriate actions to anticipate the negative impact of the pandemic. Various strategies need to be taken to strengthen the economic structure and transformation in the medium-to-long term, especially for farmers during the pandemic. 
Table 4: Internal and external factors identification

\begin{tabular}{|c|c|}
\hline Strength & Weakness \\
\hline $\begin{array}{l}\text { Suitable geographic } \\
\text { conditions }\end{array}$ & $\begin{array}{l}\text { Limited access to } \\
\text { modern technology }\end{array}$ \\
\hline $\begin{array}{l}\text { Huge domestic } \\
\text { demand }\end{array}$ & $\begin{array}{l}\text { Dependence on } \\
\text { climatic conditions }\end{array}$ \\
\hline $\begin{array}{l}\text { Availability and } \\
\text { productivity of land }\end{array}$ & $\begin{array}{l}\text { Lack of professional } \\
\text { management }\end{array}$ \\
\hline $\begin{array}{l}\text { Contributor of } \\
\text { agriculture to the } \\
\text { local economy }\end{array}$ & $\begin{array}{l}\text { Lack of market } \\
\text { availability for } \\
\text { agricultural products, } \\
\text { still dependent on } \\
\text { distributors, and } \\
\text { traditional markets. }\end{array}$ \\
\hline $\begin{array}{l}\text { The existence and } \\
\text { institutions of } \\
\text { agricultural } \\
\text { management and } \\
\text { related institutions } \\
\text { (farmer groups, } \\
\text { farmer cooperatives, } \\
\text { etc.) }\end{array}$ & \\
\hline Opportunity & Threat \\
\hline $\begin{array}{l}\text { Increase market } \\
\text { demand for chili }\end{array}$ & Global competition \\
\hline $\begin{array}{l}\text { Central government } \\
\text { support for chili } \\
\text { development }\end{array}$ & Unorganized market \\
\hline $\begin{array}{l}\text { Program } \\
\text { development } \\
\text { planning }\end{array}$ & Price Fluctuations \\
\hline $\begin{array}{l}\text { Survival of superior } \\
\text { chili varieties }\end{array}$ & $\begin{array}{l}\text { Climate change and } \\
\text { the presence of plant } \\
\text { disease organisms, } \\
\text { pests, and weeds. }\end{array}$ \\
\hline $\begin{array}{l}\text { Agricultural resource } \\
\text { potential }\end{array}$ & \\
\hline
\end{tabular}

To maintain the stability of the agricultural sector in Garut regency, a SWOT analysis was carried out to obtain the right strategy. Table 4 shows the identification of internal and external factors of chili farming in Garut regency as the initial stage of SWOT Analysis. By knowing the factors of Strengths, weaknesses, threats, and opportunities in agriculture in Garut Regency, farmers can determine strategies to continue to survive various pressures due to the COVID-19 pandemic

\section{Internal Factors}

Internal factor analysis aims at finding trends and events within the agricultural field of the chili farming sector in Garut Regency. The variables identified were from the chili agricultural sector, namely strengths and weaknesses.

1. Strength

- Suitable geographic conditions

Garut Regency is categorized as a humid tropical climate with an average rainfall around Garut regency ranging from 2,589 $\mathrm{mm}$ per year. The location of the area near the mountain also affects its temperature in the area. With these conditions, it becomes a strategic location for the agricultural industry development.

- Huge domestic demand

The demand for chili commodities in Indonesia is high because most Indonesian people like spicy foods, making many foods and snacks contain chili. This condition directly influences the demand for chili commodities.

- Availability and productivity of land

The potential harvested area in Garut reaches $5,500-6,400$ ha per year, which is supported by large chili productivity areas. The productivity of red chili peppers per year reaches 15.25 tons/ha, while for chili peppers reaches 14.24 tons/ha (Ministry of Agriculture, 2021). In addition, Garut regency provides support to other areas in West Java for chili supplies.

- Contributor of agriculture to the local economy

In the business field, the agricultural sector absorbs a workforce of $23.10 \%$, making a major contribution to the formation Garut Regency economy (BPS Garut Regency, 2018).

- The existence and institutions of agricultural management and related institutions:

The existence of farmer groups, agencies, farmer cooperatives, and others in 
managing agricultural affairs makes coordination between farmer groups or farmer-market groups to be wellcoordinated.

\section{Weakness}

- Limited access to modern technology

Cigadung subdistrict is a village located quite far from the city so that infrastructure and access to technology are not as advanced as in the city and its surroundings.

- Dependence on climatic conditions

The harvest time still follows climate conditions because no system allows farmers to deal with counter-productive climates such as drought.

- Lack of professional management

The distribution pattern of agricultural products, which has a relatively short chain, causes the agricultural sector to be not optimal. Therefore, stimulating the development of other sectors in the Garut Regency will also be not optimal. It causes the maximum gross value-added, which has implications for the low productivity of the population.

- Lack of market availability for agricultural products, still dependent on distributors and traditional markets

Farmers are still selling the chili to middlemen who will buy it below market price, and the middlemen sell the chili at market price and receive more profit. In addition, the farmers would only get a small amount of profit compared to the middlemen.

\section{External Factors}

External factor analysis aims at identifying trends and events outside the control of the chili farming sector in Garut Regency. The variables identified were not from the chili farming sector, namely, opportunities and threats faced.

1. Opportunity

- Increase market demand for chili

The trend of people regarding spicy food or snacks is rising, which makes chili consumption and product demand also rise.

- Central government support for chili development

The Agricultural Human Resources Extension and Development Agency (BPPSDMP) in 2020 has launched the Agricultural Development
Strategic Command Movement (Kostratani) program in Garut to increase agricultural productivity by conducting a program to train farmers.

- Program development planning

There is a plan to develop the agricultural sector, such as Rural Agribusiness Development (PUAP). PUAP is a form of business capital assistance facilitation for farmers, both owner farmers, sharecroppers, farm laborers, and farm households coordinated by the Farmers Association.

- Survival of superior chili varieties

Chili farmers in Garut have been introduced to the double-fold production technology (Proliga) of red chili pepper by the Research and Development Agency (Balitbangtan) and the Ministry of Agriculture (Kementan). This technology is a chili cultivation technique that can multiply farmer productivity and introduce superior chili varieties, namely carvi agrihorti chili.

- Agricultural resource potential

The potential of chili farming still has a lot of potential because chili production can still be increased further.

2. Threat

- Global competition

Indonesia has a high demand for chili commodities, but with production that has not met market demand, the government often imports chili.

- Unorganized market

The dominant harvest is distributed to the main market because village collectors face price fluctuations to get a higher price. Farmers depend on collecting traders because of limited knowledge. Besides, farmers also do not have transportations to distribute red chili peppers.

\section{- Price Fluctuations}

Lack of control and supervision over distribution could lead to hoarding or delivery loss, thereby increasing market prices.

- Climate change and the presence of plant disease organisms, pests, and weeds

Changes in the world's climate can disrupt atmosphere stability in the fields. Viruses, pests, and weeds can also kill or reduce the 
quality of chili plants, especially with the use of excess chemicals that can strengthen existing viruses or pests in the long term.

\section{SWOT Matrix}

The strategies to help maintain the agricultural sector's stability, especially chili commodities in Garut Regency, are presented based on four strategies, namely SO, WO, ST, and WT (Table 5).

\section{- S-O Strategy}

1. Increase the promotion of superior products Increased marketing of superior products can be popular faster because the uniqueness of the product can stand out more than other similar products. In addition, the promotion of superior products can also be interpreted as an effort to compete in local and international markets.

2. Improve the quality and quantity of chili products

By increasing the quality and quantity of the product, chili commodities will increase supply and demand from the community. More supply can also keep commodity prices within reasonable limits.

3. Optimization of existing land use

Land optimization means maximizing production, which directly contributes to chili commodities. However, land expansion is not the main focus because the main focus of optimization is maximizing the potential in a land.

\section{- W-O Strategy}

1. Utilizing digital-based marketing.

The use of digital-based marketing can reach various circles of society because currently, most people have gadgets and internet access. Another effect is that farmers can apply insights about emarketing to support their family life.

2. Improving agricultural facilities and infrastructure.

Developing agricultural support facilities and infrastructure can reduce the negative impacts of various factors such as pests, diseases, or a hostile climate. It can reduce the workload and streamline the crop management process on the farmer's side.

- S-T Strategy

1. Strengthening local chili development.
Strengthening local products can maintain position and compete with foreign products. Therefore, it can maintain the welfare of farmers and the country's economy. Nationally, the development of chili quality will also be well received by the community and increase consumer satisfaction to increase the demand.

2. Facilitate the farmers in marketing the product.

By facilitating farmers, the independence of farmers will grow to minimize dependence on distributors. In addition, the possibility of hoarding chilies by individuals would be kept to a minimum. It can prevent price fluctuations caused by hoarding.

\section{- W-T Strategy}

1. Do market research.

Market research aims at identifying market needs and product management to achieve suitability. In addition, market research can also help to analyze competing products and prepare strategies to compete in market competition, especially in international markets.

2. Procurement of agricultural technology training by the government.

The training on agricultural technology aims at increasing farmers' insight and familiarize themselves with tools. In the future, it can help farmers in their work because technological innovations are aimed at helping to overcome or simplify human affairs so that farmers can achieve maximum output but with a lighter workload.

A SWOT analysis has been carried out to maintain chili's supply and competitive power to identify the factors owned by chili farmers in Garut regency as one of the chilies producing regencies in Indonesia. In addition, the Covid-19 Pandemic has also repressed various sectors in Indonesia. Therefore, handling the impact of the pandemic is also needed specifically. One solution to overcome this problem is to use technology in planning and compiling the supply chain of agricultural commodities. This technology is expected to facilitate supplydemand interface services, which will be invaluable for supply chains of highly perishable goods in the harvesting and selling of agricultural products. 
Table 5: SWOT Matrix

\begin{tabular}{|c|c|c|}
\hline Internal & $\begin{array}{l}\text { Strength: } \\
\text { 1. Suitable geographic } \\
\text { conditions } \\
\text { 2. Huge domestic demand } \\
\text { 3. Availability and productivity } \\
\text { of land } \\
\text { 4. Contributor of agriculture to } \\
\text { the local economy } \\
\text { 5. The existence and } \\
\text { institutions of agricultural } \\
\text { management and related } \\
\text { institutions (farmer groups, } \\
\text { farmer cooperatives, etc.) }\end{array}$ & $\begin{array}{l}\text { Weakness: } \\
\text { 1. Limited access to modern } \\
\text { technology } \\
\text { 2. Dependence on climatic } \\
\text { conditions } \\
\text { 3. Lack of professional } \\
\text { management } \\
\text { 4. Lack of market availability } \\
\text { for agricultural products, } \\
\text { still dependent on } \\
\text { distributors and } \\
\text { traditional markets. }\end{array}$ \\
\hline $\begin{array}{l}\text { Opportunity: } \\
\text { 1. Increase market } \\
\text { demand for chili } \\
\text { 2. Central government } \\
\text { support for chili } \\
\text { development } \\
\text { 3. Program development } \\
\text { planning } \\
\text { 4. Survival of superior } \\
\text { chili varieties } \\
\text { 5. Agricultural resource } \\
\text { potential }\end{array}$ & $\begin{array}{l}\text { S-O Strategy } \\
\text { 1. Increase the promotion of } \\
\text { superior products } \\
\text { 2. Improve the quality and } \\
\text { quantity of chili products } \\
\text { 3. Optimization of existing land } \\
\text { use }\end{array}$ & $\begin{array}{l}\text { W-O Strategy } \\
\text { 1. Utilizing digital-based } \\
\text { marketing } \\
\text { 2. Improving agricultural } \\
\text { facilities and } \\
\text { infrastructure }\end{array}$ \\
\hline $\begin{array}{l}\text { Threat: } \\
\text { 1. Global competition } \\
\text { 2. Unorganized market } \\
\text { 3. Price Fluctuations } \\
\text { 4. Climate change and the } \\
\text { presence of plant } \\
\text { disease organisms, } \\
\text { pests, and weeds. }\end{array}$ & $\begin{array}{l}\text { S-T Strategy } \\
\text { 1. Strengthening local chili } \\
\text { development } \\
\text { 2. Facilitate the farmers in } \\
\text { marketing the product }\end{array}$ & $\begin{array}{l}\text { W-T Strategy } \\
\text { 1. Do market research } \\
\text { 2. Procurement of } \\
\text { agricultural technology } \\
\text { training by the } \\
\text { government to update } \\
\text { chili farmers' knowledge }\end{array}$ \\
\hline
\end{tabular}

\section{CONCLUSION}

Garut Regency's agricultural sector contributes about $40 \%$ to the agricultural economy in the surrounding area. However, traditional agricultural management has resulted in slow economic growth. The Covid-19 Pandemic has an impact on farmers. A survey conducted in the Cigedug subdistrict in Garut regency shows that the government's policy regarding restrictions on work mobilization to overcome the Covid-19 Pandemic has made it difficult for farmers to obtain fertilizers feed and agricultural supporting instruments. It is due to distribution disturbances that affect the economy of farmers both in the field of production, distribution, or sale. Entrepreneurship in the agricultural sector needs to be developed as an important tool to support and improve the economy of rural farmers, especially during the pandemic. The application of agricultural entrepreneurship can be achieved with public awareness for entrepreneurship, good business management skills, and support from the government. Therefore, they can survive in the face of 
problems in the agricultural business. With this problem, the right and effective strategy is needed to improve economic quality during the pandemic. The SWOT analysis results based on internal and external agricultural factors in Garut regency obtained several strategies, including training by the government to farmers to increase farmer knowledge, increase production of superior commodities, improve farmer facilities and infrastructure, and utilize digitalbased marketing. With this strategy, it is expected that farmers can increase their production and welfare and strengthen national food independence.

\section{REFERENCES}

Alamsyah, M. N., Sultan, S., \& Sayuti, S. (2015). Food Security and the Futures of Farmers in Decentralisation Era: a Case Study From Sigi District Central Sulawesi. KOMUNITAS: International Journal of Indonesian Society and Culture, 7(1), 118-132.

Choudhury, K., \& Easwaran, K. (2019). Agricultural entrepreneurship in Lower Brahmaputra Valley, Assam. Journal of Global Entrepreneurship Research, 9(1), 113.

Choudhury, K., \& Easwaran, K. (2019). Agricultural entrepreneurship in Lower Brahmaputra Valley, Assam. Journal of Global Entrepreneurship Research, 9(1), 113.

Dias, C. S., Rodrigues, R. G., \& Ferreira, J. J. (2019). Agricultural entrepreneurship: Going back to the basics. Journal of Rural Studies, 70, 125-138.

Hayuningtyas, M., \& Yuliasih, I. (2020). Peningkatan Kinerja, Mitigasi Risiko Dan Analisis Kelembagaan Pada Rantai Pasok Cabai Merah Di Kabupaten Garut. Journal of Agroindustrial Technology, 30(1).

Kazakhstan - Agricultural Sector: Privacy Shield. (2019). Privacyshield.gov. https://www.privacyshield.gov/article?id=K azakhstan-Agricultural-Sector

Kumar, A., Padhee, A. K., \& Kumar, S. (2020). How Indian agriculture should change after COVID-19. Food Security, 12(4), 837-840.

Mariyono, J., \& Sumarno, S. (2015). Chilli production and adoption of chilli-based agribusiness in Indonesia. Journal of
Agribusiness in Developing and Emerging Economies.

Moromi, G., \& Debayit, B. (2016). Baseline data on area, production and productivity of horticulture crops in north-east and Himalayan states-a study in Assam dr. Agricultural Situation in India, 73(1), 37-41.

Mukti, G. W., Kusumo, R. A. B., \& Pardian, P. (2020). Kecerdasan Kewirausahaan (Entrepreneurial Intellegence) Petani Muda Lulusan Universitas Padjajaran. Mimbar Agribisnis: Jurnal Pemikiran Masyarakat Ilmiah Berwawasan Agribisnis, 6(1), 54-64.

Outlook Ekonomi Pertanian. (2021). Perkuat Pembangunan Sektor Pertanian Kementerian Koordinator Bida ng Perekonomian Republik Indonesia. (2021). Retrieved September 20, 2021, from Ekon.go.id website: https://www.ekon.go.id/publikasi/detail/17 31/outlook-ekonomi-pertanian-2021perkuat-pembangunan-sektor-pertanian

Perwita, A. D. (2020, July). Peran Wirausaha Pertanian dalam Menghadapi Era Disrupsi Inovasi. In Forum penelitian Agro Ekonomi, 1, pp. 41-58.

Poapongsakorn, N. (2017). Transformation of the Thai agriculture in the last three decades. In Thailand Development Research Institute, Project of Leibniz University Hannover. Bangkok: A regional conference organized by RESAKSS-Asia.

Purba, D. W., Thohiron, M., Surjaningsih, D. R., Sagala, D., Ramdhini, R. N., Gandasari, D., \& Manullang, S. O. (2020). Pengantar ilmu pertanian. Yayasan Kita Menulis.

Putra, R. S. (2020). Analisis Produktivitas Sektor Pertanian Di Negara Asia Tenggara Tahun 1970-2016: Pendekatan Dea Malmquist Index (Doctoral dissertation, Universitas Airlangga).

Saiz-Rubio, V., \& Rovira-Más, F. (2020). From smart farming towards agriculture 5.0: A review on crop data management. Agronomy, 10(2), 207.

Zuraida, R., Ramdhani, A., \& Amin, A. S. (2011). Analysis of the Cultural Factors Impacts on the Development of Entrepreneurship in Garut. Jurnal Psikologi, 1(2). 


\section{ABOUT THE AUTHORS}

Senny Luckyardi, email:

senny@email.unikom.ac.id

Eddy Soeryanto Soegoto, Department of Management, Faculty of Economics and Business, Universitas Komputer Indonesia. Bandung, Indonesia.

Senny Luckyardi, Department of Management, Faculty of Economics and Business, Universitas Komputer Indonesia. Bandung, Indonesia.

Lia Warlina, Department of Urban and Regional Planning, Faculty of Engineering and Computer Science, Universitas Komputer Indonesia, Bandung, Indonesia.

Sri Supatmi, Department of Electro Engineering, Faculty of Engineering and Computer Science, Universitas Komputer Indonesia, Bandung, Indonesia. 